\title{
Wokół 200. rocznicy powołania Towarzystwa Naukowego Krakowskiego (1815-1872)
}

W 2015 r. minęła 200. rocznica powołania Towarzystwa Naukowego Krakowskiego. Towarzystwo powstało z inicjatywy rektora Uniwersytetu Krakowskiego Walentego Litwińskiego na mocy statutu uchwalonego 24 lipca 1815 r. na sesji Rady Rektorskiej. Było jedną z najstarszych, obok Towarzystwa Przyjaciół Nauk w Warszawie, Poznańskiego Towarzystwa Przyjaciół Nauk i Towarzystwa Naukowego w Toruniu, instytucją naukową o charakterze ogólnym na ziemiach polskich, a w latach 1832-1856 jedynym tego typu stowarzyszeniem. Funkcjonowało nieprzerwanie od 1815 do 1872 r. w trudnym okresie zaborów i burzliwych zawirowań politycznych. Przechodziło w ciągu swej działalności okresy rozkwitu i stagnacji, trzykrotną zmianę statutu, ale jako ważna instytucja na trwałe wpisało się w historię nauki polskiej. Sercem Towarzystwa byli jego członkowie. Wokół idei, która, jak głosił wspomniany statut, było ,pomnożenie wszelkich nauk, rozszerzenie światła, rozkrzewienie sztuki przemysłu i kunsztów w narodzie" na przestrzeni 57 lat zgromadziło się liczne grono 837 uczonych rozmaitych dyscyplin, miłośników nauki, artystów, polityków i społeczników. Wiele znanych osób, jak chociażby Adam Jerzy Czartoryski, Jan Matejko, Oskar Kolberg, Ignacy Domeyko, Józef Dietl, Józef Majer, Józef Kremer czy Józef Szujski współtworzyło Towarzystwo i pracowało na jego rzecz. Towarzystwo realizowało rozmaite inicjatywy zarówno w zakresie nauk humanistycznych, jak i przyrodniczych. Wydało m.in. 44 tomy „Rocznika Towarzystwa Naukowego Krakowskiego” w języku polskim, prowadziło badania nad zdrojowiskami krajowymi w ramach Komisji Balneologicznej, prace w obszarze botaniki, geologii i zoologii w łonie Komisji Fizjograficznej, badania w zakresie piśmiennictwa i języka polskiego realizowane przez Komisję Bibliograficzną i Językową oraz działania w zakresie archeologii i historii Polski prowadzone przez Oddział Archeologii i Sztuk Pięknych oraz Komisję Historyczną. W 1872 r. Towarzystwo zostało przekształcone w Akademię Umiejętności, która kontynuowała i rozwijała podjęte u progu XIX w. dzieło.

Jubileusz stał się znakomitą okazją do upamiętnienia i pokazania roli, jaką odegrało Towarzystwo w dziejach nauki polskiej oraz złożenia hołdu jego twórcom. Stąd też Polska Akademia Umiejętności, jako sukcesorka idei realizowanych przez Towarzystwo, wspólnie z Uniwersytetem Jagiellońskim oraz Archiwum Nauki PAN i PAU zorganizowała szereg wydarzeń, które zwieńczyła konferencja jubileuszowa zainaugurowana w dniu 9 grudnia 2015 r. w rocznicę daty zatwierdzenia statutu Towarzystwa Naukowego Krakowskiego przez władze Wolnego Miasta Krakowa. Materiały pokonferencyjne opublikowano w wydawnictwie pt. Towarzystwo Naukowe Krakowskie w 200-lecie założenia (1815-2015). Materiaty konferencji naukowej 9-10 grudnia 2015, pod redakcją prof. Jerzego Wyrozumskiego, Kraków 2016.

Wśród podjętych inicjatyw trzeba wymienić wystąpienia w ramach Kawiarni Naukowej PAU. Pierwsze burmistrza Krynicy-Zdroju dr. Dariusza Reśki pt. „Krynica-Zdrój - kurort 
tradycji i nowoczesności. Co powinno zwyciężyć?” wygłoszone 23 listopada 2015 r. Drugie prof. Franciszka Ziejki pt. „Zaczęło się przed 200 laty... (O Towarzystwie Naukowym Krakowskim, jego burzliwych dziejach i końcu, który był początkiem)”, które miało miejsce 7 grudnia 2015 r. i zostało wydane drukiem przez PAU w cyklu „Wykłady” w 2016 r. W ramach jubileuszu PAU 8 grudnia 2015 r. zorganizowała również debatę o problemach społecznego ruchu naukowego w Polsce, natomiast 10 grudnia 2015 r. prezes PAU prof. Andrzej Białas oraz wiceprezesi prof. Andrzej Borowski i prof. Andrzej Kajetan Wróblewski gościli w TVP Kraków w audycji poświęconej roli Towarzystwa Naukowego Krakowskiego i Polskiej Akademii Umiejętności w życiu naukowym Krakowa i ziem polskich.

W cykl przedsięwzięć wpisały się również takie, które miały na celu przybliżenie szerszemu gronu odbiorców, a w szczególności młodzieży, problematyki związanej z Towarzystwem Naukowym Krakowskim. Takie zadanie spełnił zorganizowany wspólnie z Kuratorium Oświaty w Krakowie i XI Liceum Ogólnokształcącym im. Marii Dąbrowskiej w Krakowie ogólnopolski konkurs ,200. rocznica utworzenia Towarzystwa Naukowego Krakowskiego" dla uczniów szkół gimnazjalnych i ponadgimnazjalnych, który spotkał się z bardzo dużym zainteresowaniem. Wyłonieni laureaci zaprezentowali najlepsze prace w czasie konferencji jubileuszowej i odebrali nagrody i wyróżnienia.

Upowszechnieniu jubileuszu Towarzystwa oraz informacji o jego historii i działalności służy również strona jubileuszowa uruchomiona 19 czerwca 2015 r. Witryna dostępna pod adresem: http://www.tnk.krakow.pl pozwala prezentować informacje o prezesach i członkach Towarzystwa oraz unikatowe materiały archiwalne z zespołu akt Towarzystwa Naukowego Krakowskiego przechowywane w zasobie Archiwum Nauki PAN i PAU w Krakowie.

Archiwum Nauki w ramach obchodów jubileuszowych postanowiło kontynuować systematycznie prowadzone od wielu lat prace nad owym unikatowym, zachowanym prawie w całości, zespołem XIX-wiecznych akt Towarzystwa. Wydany w 1959 r. przez Danutę Rederową inwentarz akt musiał zostać uaktualniony wobec zmian w metodyce archiwalnej, dopływu ok. $1 \mathrm{mb}$ akt oraz rozwoju technologii informacyjno-komunikacyjnych dających możliwości nowoczesnego zabezpieczenia i udostępnienia archiwaliów. Dokonano przeglądu oraz nowego podziału jednostek archiwalnych, a także uporządkowano i włączono dopływy archiwaliów. Materiały poddano zabiegom konserwatorskim oraz digitalizacji przeprowadzonej w kilku etapach. Prace zakończyły się opracowaniem nowego inwentarza zawierającego 195 jednostek, obejmującego ok. 3 mb akt. Uwzględnia on informacje o częściach zespołu Towarzystwa Naukowego Krakowskiego znajdujących się w Archiwum UJ i Bibliotece Jagiellońskiej, które Archiwum Nauki posiada w formie elektronicznej. W oparciu o nowy inwentarz w grudniu 2016 r. we współpracy z informatykiem na stronie http://inwentarz.tnk.krakow.pl. udostępniono pierwszą część zdigitalizowanych materiałów (ok. 8600 skanów) z możliwością wyszukiwania nazwisk w dziennikach podawczych korespondencji Prezesa Towarzystwa.

Akta Towarzystwa Naukowego zainspirowały Archiwum Nauki do opublikowania pocztu członków Towarzystwa. Przygotowano spis 837 członków czynnych, korespondentów i honorowych wraz $\mathrm{z}$ datami ich wyboru, który został udostępniony na wspomnianej wyżej stronie internetowej. Zgromadzono również materiały do biogramów członków, które są w trakcie opracowywania. 
Archiwum z myślą o zachowaniu pamięci o dorobku przeszłych pokoleń, złożeniu hołdu uczonym - wybitnym krzewicielom światła i umiejętności, twórcom Towarzystwa Naukowego Krakowskiego, przygotowało dwie wystawy prezentowane w sali wystawowej Archiwum Nauki przy ul. św. Jana 26 oraz dwie ekspozycje posterowe w holu PAU przy ul. Sławkowskiej 17. Na pierwszej, zatytułowanej „Wspólnota umiłowania nauki. 200. rocznica powołania Towarzystwa Naukowego Krakowskiego" (19 czerwca - 30 października 2015 r.), pokazano archiwalia i muzealia obrazujące założenie i podstawy organizacyjno-prawne Towarzystwa. Równocześnie w holu PAU prezentowano postery przedstawiające wizerunki prezesów Towarzystwa, które następnie przeniesiono na Planty krakowskie, gdzie eksponowano je od 4 do 31 sierpnia 2015 r. Obie wystawy można obejrzeć w formie wirtualnego spaceru na stronie http://pau.wkraj.pl. Kolejna wystawa pt. „Wznosząc gmach narodowej wiedzy. 200. rocznica powołania Towarzystwa Naukowego Krakowskiego” (9 grudnia 2015 - 30 marca 2016) wraz z częścią posterową pt. „Gdy jedna myśl rodzi drugą. Towarzystwo Naukowe staje się Akademią Umiejętności” została poświęcona historii i działalności Towarzystwa. Wystawom towarzyszyły bogato ilustrowane, opatrzone tekstami źródłowymi publikacje o tych samych tytułach. Ekspozycje opracowane przez Archiwum Nauki służyły spopularyzowaniu wiedzy o jednej z najstarszych instytucji naukowych na ziemiach polskich.

Czerpiąc z XIX-wiecznych tradycji, kiedy to z okazji jubileuszu swego istnienia w $1868 \mathrm{r}$. Towarzystwo wydało Pamiatkę obchodów pięćdziesięcioletniej rocznicy zawiazania Towarzystwa Naukowego Krakowskiego, Polska Akademia Umiejętności dla upamiętnienia 200-lecia Towarzystwa Naukowego Krakowskiego przygotowała okolicznościową publikację zatytułowaną Pamiatka 200. rocznicy zawiazania Towarzystwa Naukowego Krakowskiego. W wydawnictwie zawarto reprint Rytmu na uroczystość pięćdziesięcioletniej rocznicy od założenia Towarzystwa Naukowego Krakowskiego autorstwa Wincentego Pola, poprzedzony słowem wstępnym prof. Jerzego Wyrozumskiego i tekstem prof. Franciszka Ziejki Wincenty Pol a Towarzystwo Naukowe Krakowskie.

$\mathrm{Z}$ okazji jubileuszu Towarzystwa, któremu przyświecała idea pojmowania nauki jako uniwersalnej wartości uprawianej dla dobra ogółu i przyszłych pokoleń, wybito okolicznościowy medal według projektu prof. Stefana Dousy. Na awersie znajduje się wizerunek siedziby PAU wybudowanej w latach 50. XIX w. z inicjatywy prezesa Towarzystwa Naukowego Franciszka Wężyka, pieczęcie Towarzystwa i PAU oraz napis „Towarzystwo Naukowe Krakowskie 200 lat”. Na rewersie przedstawiono panoramę Krakowa z napisem „Scire tuum nihil est, nisi te scire hoc sciat alter" - dewizę Towarzystwa Naukowego zaczerpniętą z łacińskiego poety Aulusa Persjusza Flaccusa, wyrażającą sens zrzeszania się uczonych.

Mamy nadzieję, iż obchody 200. rocznicy powołania Towarzystwa Naukowego Krakowskiego były, jak pisał o jubileuszach w książce pt. Od Towarzystwa Naukowego Krakowskiego do Polskiej Akademii Umiejętności Piotr Hübner, istotnym czynnikiem transferu wartości i nośnikiem dziedzictwa kulturowego, który poprzez tradycję łączy czasy dawne ze współczesnością.

Marcin Maciuk, Matgorzata Mrówka Archiwum Nauki PAN i PAU w Krakowie 